\title{
Life Cycle and Reproductive Parameters of Clerada apicicornis Signoret (Hemiptera: Lygaeidae) under Laboratory Conditions
}

\author{
Estrella Cárdenas ${ }^{+}$, Alberto Morales, Mariela Torres
}

Laboratorio de Entomología, Instituto Nacional de Salud, Avenida Eldorado, Carrera 50, Zona Postal 6, Apartado Aéreo 80080, Santa Fe de Bogotá, Colombia

The life cycle of Clerada apicicornis was determined under laboratory conditions. Mean development times in days were: egg 27.2, nymph I 12.5, nymph II 12, nymph III 13.4, nymph IV 16.4, nymph V26. The life expectancy of adults ranged from 117 to 317 days (mean 196 days). Based on a cohort of 29 females of $\mathrm{C}$. apicicornis, a horizontal life table was constructed. The following predictive parameters were obtained: net rate of reproduction $\left(R_{o}=48.31\right)$, intrinsic rate of population increase $\left(r_{m}=0.153\right)$, generation time (Tc $=28.20$ weeks), and finite rate of population increment $(\lambda=1.16)$. The reproductive value $\left(V_{x}\right)$ for each age class of the cohort females was calculated. The following observed parameters were calculated after mortality in each stage: net rate of reproduction $\left(R_{o}^{\prime}=13.4\right)$, intrinsic rate of population increase $\left(r_{c}{ }^{\prime}=0.09\right)$, and finite rate of population increment $\left(\lambda{ }^{\prime}=1.1\right)$. The generation time $\left(T_{c}{ }^{\prime}=27.4\right)$ was estimated using the methods of Laughlin and Bengstron. A vertical life table was elaborated and mortality was described for one generation of the cohort.

Key words: Clerada apicicornis - life cycle - life tables - population parameters - mortality

The bug Clerada apicicornis Signoret has a broad geographical distribution in the tropical zone of both Eastern and Western Hemispheres (Malipatil 1981, 1983). This species has been reported in Singapore associated with Triatoma rubrofasciata (Simmonds 1971), and was first recorded in Colombia by Bonilla-Naar (1948), where it was observed feeding on Rhodnius prolixus during an effort to colonise it in the laboratory. $C$. apicicornis has been proposed as a potential vector of Chagas disease, because of its presence in houses (Castro-Ferreira \& Deane 1938a,b) and detection of vertebrate blood in its intestine (Harrington 1990). Under laboratory conditions, this bug fed very well on $R$. prolixus and cockroaches (Blaberus atropus) suggesting that its predatory feeding could be useful for the potential biological control of some arthropod vectors (Simmonds 1971). Under experimental conditions it also fed on mouse, hamster, rabbit, and turkey (Torres et al. 2000).

This research was supported by Colciencias Basic Science Program and by Instituto Nacional de Salud, Colombia.

${ }^{+}$Corresponding author. Fax: (571) 315.7341. E-mail: ecardenas95@latinmail.com

Received 7 August 2000

Accepted 4 September 2000
During the past six years, the Entomology Laboratory, Instituto Nacional de Salud, has maintained a colony of C. apicicornis initiated from specimens collected from rural human dwellings in the municipality of Guateque, Boyacá Department, Colombia. However, the biology of this species has not been studied in depth. To better understand the reproductive biology, a horizontal life table was constructed based on the development time of each instar of the progeny of 29 cohort females, with observed and predictive population parameters being calculated. A vertical life table was constructed and the mortality was described for each instar of one generation.

\section{MATERIALS AND METHODS}

The study was carried out between 1995 to 1996 with specimens from the laboratory colony. The experimental conditions were: relative humidity ranging from $44.5 \%$ to $78 \%$ (mean $61.8 \%$ ), minimum temperature ranging from $17.5^{\circ} \mathrm{C}$ to $26^{\circ} \mathrm{C}$ (mean $19.9^{\circ} \mathrm{C}$ ) and maximum temperature ranging from $20^{\circ} \mathrm{C}$ to $31^{\circ} \mathrm{C}$ (mean $22.7^{\circ} \mathrm{C}$ ).

The cohort was initiated with 29 couples (female-male) of 5th-stage nymphs which were sexed and separated by size. Each couple was separated into a glass container $(13 \times 7 \mathrm{~cm})$, with a cockroach (B. atropus) introduced for their nourishment, and a folded white paper $(8 \times 8 \mathrm{~cm})$ placed into each container as an artificial habitat of the bugs and the cockroaches. The container was covered with a piece of white cloth and sealed with 
a rubber band. When the adults emerged, all the couples were checked to confirm the sex of the specimens. Each day a new folded white paper was introduced into each container for oviposition. The paper with attached eggs was transferred to another labelled glass container, where egg development was observed. Data were recorded daily for survivor cohort females, eggs laid by each female, the nymphs and adults obtained per each female. Data from the cohort were converted into weeks and then subject to the methods of calculation described by Pianka (1988), Rabinovich (1980), and Southwood (1978), as they were compiled and used for Lutzomyia shannoni (Cárdenas et al. 1999). The life cycle of $C$. apicicornis was estimated by daily monitoring of the development of eggs oviposited by 10 females.

\section{RESULTS}

Description of the development stages

Egg - The eggs of C. apicicornis were elongated oval and measured $1.5 \mathrm{~mm}$ in length and $0.4 \mathrm{~mm}$ wide. The eggs were light brown in colour with granulous sculpturing over chorium; the micropyle extreme was flat with a variable number
(14-17) of micropyle processes (Fig. 1A). The mean incubation time was 27.2 days with a range of 26 to 28 days.

First instar nymphs - The body length was 1.8 $\mathrm{mm}$. The head, thorax, legs, and the first three antennal segments were light grey, while the fourth one was pale yellow, and the abdomen dark yellow in colour (Fig. 1B). The development time of this stage ranged from 11 to 14 days (mean 12.5).

Second instar nymphs - The body colour was similar to that of the first instar, but this stage was larger in size (Fig. 1C). The development time of this instar ranged from 11 to 14 days (mean 12).

Third instar nymphs - The body colour was similar to that of the first and second stages, but larger in size (Fig. 1D). The development time of this instar ranged from 11 to 15 days (mean 13.4).

Fourth instar nymphs - The body length reached $4 \mathrm{~mm}$. The head, and legs were grey, with the first three antennal segments dark brown while the fourth one pale yellow in colour. The thorax was dark brown with a grey sculpture over the dorsum. The abdomen was red with three brown spots over the dorsum (Fig. 1E). The development time of this instar ranged from 15 to 18 days (mean 16.4).

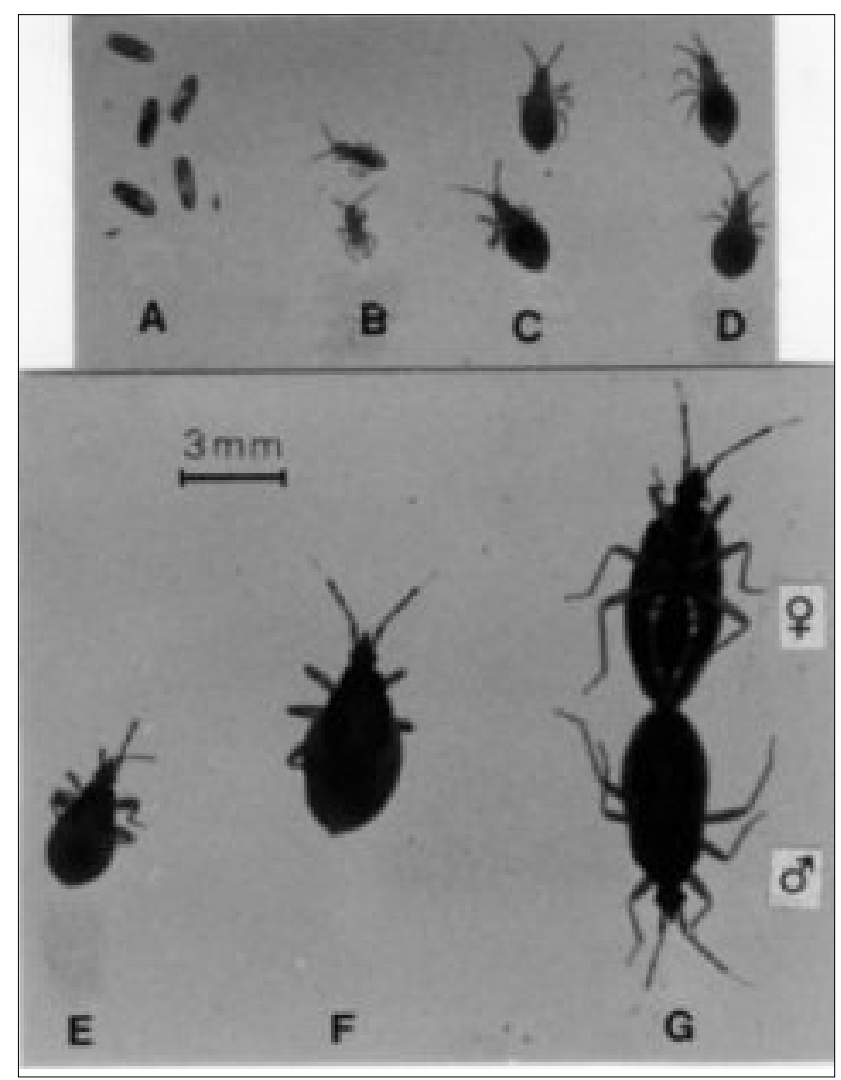

Fig. 1: development stages of Clerada apicicornis. A: eggs; B: first instar nymphs; C: 2nd instar nymphs; D: 3rd instar nymphs; E: 4th instar nymph; F: 5th instar nymph; G: adults 
Fifth instar nymphs - The body length reached $6 \mathrm{~mm}$. The head and the legs were light brown while the antennal segments were similar in colour to those of the fourth instar. The thorax and hemelytra were dark brown with yellow sculpture (Fig. 1F). The development time of this instar ranged from 22.5 to 29 days (mean 26).

Adults - The external morphology was as described by Lent (1939) (Fig. 1G-H). The complete life cycle from egg to adult ranged from 100 to 115 days (mean 108.8) in males, while in the female it ranged from 100 to 112 days (mean 106.5). The male longevity ranged from 77 to 317 days (mean 220) while the female longevity ranged from 117 to 275 days (mean 172).

\section{Population parameters}

Horizontal life table and predictive population parameters - A horizontal life table was constructed and the predictive population parameters estimated in absence of mortality according to Southwood (1978). From the horizontal life table, the following values were obtained for predictive population parameters: net reproductive rate $R_{o}=48.31$ female daughters per cohort female in a generation; generation time $T_{c}=28.20$ weeks (average age of the generation cohort females in which was concentrated the reproductive effort); $r_{m}=0.153$ daughter females for each cohort female per week; and finite rate of increase $\lambda=1.16$ individuals per female per week. The reproductive values per age class of the cohort females were estimated. The reproductive value $\left(V_{x}\right)$, fertility $\left(m_{x}\right)$ and cohort females survival $\left(l_{x}\right)$ versus cohort females age $(x)$ were plotted (Fig. 2). The increase in reproductive value was exponential (despite a fecundity of zero between 0.5 to 15.5 weeks) until the females reached an age of 18.5 weeks, when oviposition was initiated confirming the theoretical expectation. At 18.5 weeks the $V_{x}$ reached the maximum peak, this value coincided with a maximum peak of fecundity. $V_{x}$, then decreased slowly until 53.5 weeks, while the fecundity $\left(m_{x}\right)$ of the surviving cohort females $\left(l_{x}\right)$ was fluctuated between 0.25 and 3.5 eggs per female per week.

Observed population parameters - A total of 786 adults from 29 cohort females was obtained (Table I), 390 daughter females and 396 males. The replacement rate $R_{o}$ ' $=13.4$ daughter females per cohort female was estimated. The generation time $T_{c}=27.4$ weeks was estimated using methods of Laughlin and Bengstron (Southwood 1978) (Fig. 3 ). The innate capacity of population increase was $r_{c}{ }^{\prime}=0.09$ daughter females per cohort female per week. The finite rate of increase was $\lambda^{\prime}=1.1$ individuals per female per week.

\section{Analysis of the stage-specific mortality}

A vertical life table was constructed based on the $l_{x}$ (live individuals) and $d_{x}$ (mortality) at each instar. Stage-specific mortality was based on data in the vertical life table according to Southwood (1978) (Table I).

Egg mortality - From the 29 cohort females of C. apicicornis, 2,803 oviposited eggs were obtained, and the mortality was $48.1 \%$. The irreplaceable mortality in oviposited eggs was $26.2 \%$. Without this mortality, an additional 673

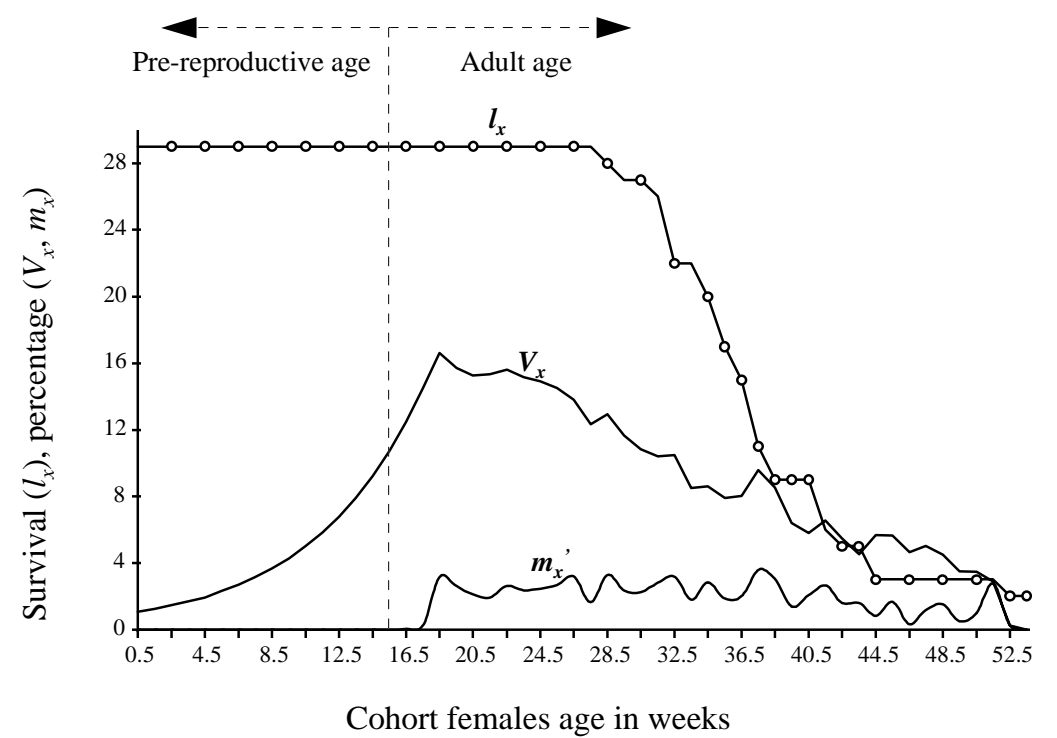

Fig. 2: survival $\left(l_{x}\right)$, fertility $\left(m_{x}\right)$, and reproductive value $\left(V_{x}\right)$ in function of the cohort females age in weeks of Clerada apicicornis. 


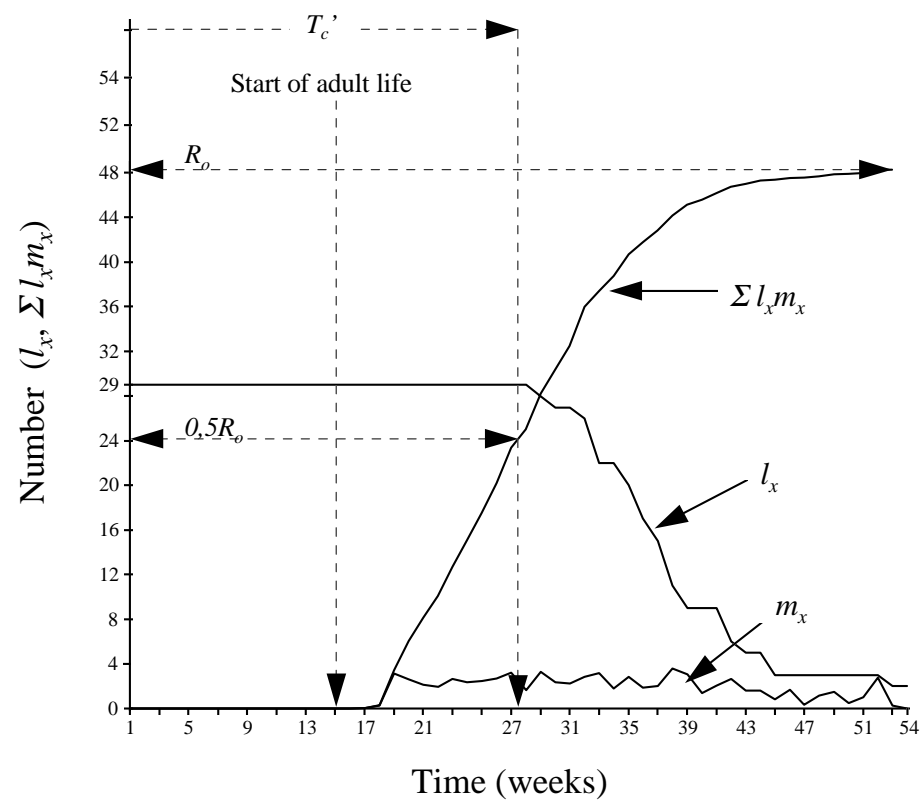

Fig. 3: population growth data for Clerada apicicornis displayed to illustrate the values used to make approximate estimates of cohort generation time $\left(T_{c}\right)$, following the methods of Laughlin and Bengstron (Southwood 1978).

eggs would have ecloded for a total of 2,130 1stinstar nymphs.

Nymph mortality - The second type of significant mortality occurred in the 1 st-instar $(12.5 \%)$. The irreplaceable mortality was $9 \%$. Without this mortality, an additional 1731 st-instar nymphs would have passed to the following instar making a total of 1,282 2nd-instar nymphs. The mortality of 2nd-instar nymphs was $4.7 \%$. Without irreplaceable mortality (3.9\%) an additional 64 nymphs of 2nd-instar would have passed to the following stage for a total of 1,041 3rd-instar nymphs. The mortality at 3rd-instar nymphs was $2 \%$. Without irreplaceable mortality $(1.8 \%)$ an additional 61 nymphs would have passed to the following stage for a total of 977 4th-instar nymphs. The mortality at 4th-instar nymphs was $2.1 \%$. Without irreplaceable mortality (2\%) an additional 77 nymphs (4th instar) would have passed to the following stage for a total of 993 5th-instar nymphs. The mortality at the 5th-instar was $2.6 \%$. Without irreplaceable mortality (2.6\%) an additional 72 (5th-instar nymphs) would have passed to the following stage for a total of 930 adults.

\section{DISCUSSION}

Comparing the development time in days of $C$. apicicornis obtained in this study with those reported by Simmonds (1971), the complete life cycle from egg to adult male coincided (mean 108.8 vs 109), and also the 2nd-instar (11-14 vs 12-13); while the egg (mean 27.2 vs 18), and 1st-instar (11-14 vs 7-8) were very different.

This is the first report for this bug of the reproductive biology based on life table. According to the data obtained, C. apicicornis has a long life cycle like most other hemimetabolous insects (Truman \& Riddiford 1999). We concluded that this species is a K-strategist and its demographic explosion is prey-dependent. Specific data on population parameters for comparison with other species of Lygaeidae are not available. Observing the population parameters of C. apicicornis (data of the present work), with those for $R$. prolixus from Venezuela and T. infestans from Chile (data of Rabinovich 1972, 1980), a similarity was observed between $C$. apicicornis and $R$. prolixus that did not exist with $T$. infestans (Table II).

The laboratory data providing essential baseline information concerning the reproductive potential for $C$. apicicornis need to be complemented by studies of reproductive biology in the field.

The study of $C$. apicicornis- $R$. prolixus interactions in the laboratory and in the field will be essential in order to evaluate the real predator-capacity of $C$. apicicornis and to determine the real vector-capacity in the transmission of Chagas disease, so that we can properly involve or reject this insect in biological control. 
TABLE I

Temporal life table of a generation of Clerada apicicornis to analyse mortality under laboratory conditions

\begin{tabular}{lrcccc}
\hline $\begin{array}{l}\text { Development } \\
\text { stages }\end{array}$ & $l_{x}$ & $d_{x}$ & $\begin{array}{c}\text { \% apparent } \\
\text { mortality }\end{array}$ & $\begin{array}{c}\% \text { real } \\
\text { mortality }\end{array}$ & $\begin{array}{c}\text { \% irreplaceable } \\
\text { mortality }\end{array}$ \\
\hline Eggs & 2,803 & 1,348 & 48.1 & 48.1 & 26.2 \\
Nymphs I & 1,455 & 350 & 24 & 12.5 & 9 \\
Nymphs II & 1,105 & 132 & 11.9 & 4.7 & 3.9 \\
Nymphs III & 973 & 57 & 5.8 & 2 & 1.8 \\
Nymphs IV & 916 & 58 & 6.3 & 2.1 & 2.6 \\
Nymphs V & 858 & 72 & 8.4 & & 2.6 \\
Adults & 786 & & & & \\
\hline
\end{tabular}

$\overline{l_{x}}$ : number of individuals that enter into a specific stage; $d_{x}$ : number of individuals that died within a specific stage.

TABLE II

Population parameters of Clerada apicicornis, Rhodnius prolixus, and Triatoma infestans (time in weeks)

\begin{tabular}{lccc}
\hline Parameters & C.apicicornis & R. prolixus & T. infestans \\
\hline Net reproductive rate $\left(R_{o}\right)$ & 48.31 & 49.30 & 25.00 \\
Generation time $\left(T_{c}\right)$ & 28.20 & 28.24 & 30.87 \\
Intrinsic rate of population increase $\left(r_{m}\right)$ & 0.153 & 0.165 & 0.102 \\
Finite rate of population increment $(\lambda)$ & 1.16 & 1.01 & 1.11 \\
\hline
\end{tabular}

The parameters of R. prolixus and T. infestans initially calculated in days (Rabinovich 1980) are shown in weeks.

\section{ACKNOWLEDGMENTS}

To Dr Cristina Ferro, co-ordinator of Entomology Laboratory, Instituto Nacional de Salud of Colombia, whose suggestions greatly improved the presentation of this manuscript.

\section{REFERENCES}

Bonilla-Naar A 1948. Un nuevo triatoma, el Panstrongylus geniculatus (Latreille, 1811) Pinto 1931. Repertorio de Medicina y Cirugía 3: 738-746.

Cárdenas E, Ferro C, Corredor D, Martínez O, Munstermann LE 1999. Reproductive biology of Lutzomyia shanonni (Dyar) (Diptera: Psychodidae) under experimental conditions. J Vect Ecol 24: 158170.

Castro-Ferreira L, Deane L 1938a. Encontro de um novo hematófago do homem com hábitos domiciliares. Brasil Medico 52: 1137-1141.

Castro-Ferreira L, Deane L 1938b. Infecção experimental do Clerada apicicornis Signoret 1863, pelo Shizothrypamum cruzi Chagas 1909 (Nota prévia). Brasil Medico 52: 1181.

Harrington BJ 1990. Detecting evidence of haematophagy in dry museum specimens of Clerada apicicornis (Hemiptera: Lygaeidae: Rhyparochrominae). Ann Entomol Soc Am 83: 545-548.

Lent H 1939. Sobre o hematofagismo da Clerada apicicornis e outros artrópodos; sua importância na transmissão da doença de Chagas. Mem Inst Oswaldo Cruz 34: 583-606.
Malipatil MB 1981. Revision of Australian Cleradini (Heteroptera: Lygaeidae). Aust J Zool 29: 773-819.

Malipatil MB 1983. Revision of world Cleradini (Heteroptera: Lygaeidae), with a cladistic analysis of relationships within the tribe. Aust J Zool 31: 205-225.

Pianka ER 1988. Evolutionary Ecology, 4th ed., Harper \& Row, Publishers, New York, 468 pp.

Rabinovich JE 1972. Vital statistics of Triatominae (Hemiptera: Reduviidae) under laboratory conditions. I. Triatoma infestans Klug. J Med Entomol 9: 351-370.

Rabinovich JE 1980. Introducción a la Ecología de Poblaciones Animales, Compañía Editorial Continental S.A., Mexico, 313 pp.

Simmonds FJ 1971. Report on investigations into natural enemies of Triatoma for the World Health Organization. Commonwealth Institute of Biological Control, Curupe, Trinidad, 13 pp.

Southwood TRE 1978. Ecological Methods, with Particular Reference to the Study of Insect Populations, 2nd ed., Chapman and Hall, London and New York, 524 pp.

Torres M, Cárdenas E, Perez S, Morales A 2000. Haematophagy and cleptohaematophagy of Clerada apicicornis (Hemiptera: Lygaeidae), a potential biological control agent of Rhodnius prolixus (Hemiptera: Reduviidae). Mem Inst Oswaldo Cruz, 95: 131-133.

Truman JW, Riddiford LM 1999. The origins of insect metamorphosis. Nature 401: 447-452. 